\title{
Attitude and Perception of Ghanaians toward the Church
}

\section{An Analysis of the views of Christians living in selected Districts in the Greater Accra Region of Ghana}

\author{
Joseph Bawa | ORCID: 0000-0001-8761-9348 \\ Department of Distance Education/Political Science, University of Ghana, \\ Legon, Ghana \\ Corresponding author \\ jbawa8o@gmail.com/jobawa@ug.edu.gh
}

\author{
Anthony Ayim | ORCID: 0000-0002-9068-8528 \\ Department of Distance Education/Sociology, University of Ghana, \\ Legon, Ghana \\ eliayim@yahoo.com/aayim@ug.edu.gh
}

\author{
Bossman Bastimi | ORCID: 0000-0002-2031-4053 \\ Divine Congregation (Madina NOP), Presbyterian Church of Ghana, \\ Accra, Ghana \\ imitsabakanlug@gmail.com
}

\begin{abstract}
Although a secular state by legislation, Ghana is highly considered a religious one with a significant number of the population being Christians. Using Christians in some selected municipalities in the Greater Accra Region of Ghana, this study examines the opinions of believers toward Ghanaian churches. Through a quantitative method, the study revealed that prayer service is the least important practice of the church liked by Christians. In addition, majority of Christians disliked their churches because of unfaithful pastors, long sermons and late closure of church services. Again, the study revealed that churches concentrate on the message of personal prosperity more than repentance toward salvation. They have an overly monetized and materialistic leaning in their sermons. The study recommends the need for churches in Ghana to leverage on the importance of research on regular basis to ascertain the opinions of the members to give churches the right direction to develop.
\end{abstract}




\section{Keywords}

Believers - Christianity - Church - Ghana - God - Greater Accra

\section{Introduction}

It is important to note that churches universally and those in Ghana in particular have for the past years invested massively in both their spiritual and physical growth. Ghana is generally considered as a Christian country partly because about 71.2 percent of the population are Christians (Ghana Statistical Service 2012). In fact the Ghanaian Christian is highly considered to be churchical (Gyampo and Asare 2015). It is in line with this that the leadership of the church is constantly exploring various means of attaining plausible and actionable roadmaps to meet the overall goal and mission of the church which is primarily to win souls for the kingdom of God. This obviously requires leadership to constantly create the necessary conduit for its members to participate fully in all the activities of the church in order to facilitate its growth. Invariably, it is very imperative for the church to have an effective plan for sustaining its mission and purpose. This requires the development of a comprehensive action plan on the part of the leadership to keep track of the general growth of their members and the church as a whole.

In fact it is very imperative again to note that there cannot be a church without members. Thus, it is the coming together of the members that makes a church to be truly considered a church. This requires a rigorous implementation of the desired interests of the members of the church in line with the Word of God. The members of the church also have a responsibility on their shoulders to see to it that the church is performing its functions in accordance with the Word of God. Therefore, the believer in no way has to see the church as a welfare organization as some are tempted to believe. This requires the members to be active rather passive in the church. Believers who call themselves followers of Christ must have the right attitude toward the church, fundamentally as a sacred institution. It is an obvious fact that vibrant and active members will produce a vibrant church. The church as an entity and spiritual institution needs to be assessed occasionally in order to track its development and progress especially on how it keeps evolving. This needs to be done through studious scientific research which examines the views of the members of the church. It is for this reason that ecclesiology ${ }^{1}$ continues to be one of the important fields of Christian theological studies. This study seeks to provide empirical evidence on what believers like and dislike about their churches as well as 
investigating the growing perceptions about the church. Thus, it contributes to the existing literature on the changing nature of the church from the perspectives of believers.

Using Christians in some selected municipalities in the Greater Accra Region of Ghana as case study, this work seeks to investigate their attitude and perception toward both the spiritual and physical growth of the church. As noted earlier, Ghana is highly considered as a religious nation with majority of the citizens being the followers of Jesus Christ. Based on the findings, recommendations will be drawn for churches in Ghana and the rest of the world. The study seeks to achieve three main objectives: (1) To examine the demographic characteristics of believers (2) To examine the views of believers on church services and activities (3) To examine the perception of believers about Ghanaian churches.

\section{The Conception of the Church}

The church has been defined to mean so many things in Christian theology. The word church was first used in the Christian sense in Acts 5:11 and primarily referred to as local congregations (Goodhew 2015). It has been argued that the conception of the church in today's society comes with a lot of confusion. Clowney (1987) argues that we cannot understand the meaning of the church with sociological analysis. Bulgakov (1988) sees the church as the Incarnation and Body of Christ. Similarly, in the view of Acquah (2012: 22), the church is the Body of Christ, of which Christ is the Head. To Acquah (2012), it is unbiblical to conceptualize the church as a building. Thus, the church has been referred to as the personality of Christ. It is from this that the Bible says the bodies of believers are the temple of God. This is what Apostle Paul admonishes Christians to understand as a fundamental idea about their relationship with Christ. We can therefore define the church as a group of people called out of the world to represent the body of Christ on earth. This is the literal conception of the church. However, biblically the church represents the individual believer as Apostle Paul rightly noted in 1 Corinthians 6:19 (KJV): 'What? Know ye not that your body is the temple of the Holy Ghost which is in you, which ye have of God, and ye are not your own?'

Christ, in His interaction with the Samaritan woman, declared that: 'But the hour cometh, and now is, when the true worshippers shall worship the Father in spirit and in truth: for the Father seeketh such to worship him' (John 4:23 [KJv]). By this, Christ attributes God's temple or place of worship to be the individual. When Jesus declared that He will destroy the temple and rebuild 
it in three days, the Pharisees took it as an offence because they understood this in their carnal minds that Christ meant destroying the physical structure which they spent several years to build. Little did they know that Christ referred to His own body. He fulfilled this when He died and resurrected on the third day. The word church also epitomizes a sacred institution where believers or followers of Christ worship.

Etymologically, the word church is translated from the Greek term ekklesia and it is used in the New Testament (NT) primarily to mean the community of believers or followers of Jesus Christ. It is out of this that we have a congregation. The concept is therefore plainly used to mean congregation, assembly, or meeting. However, although the word church assumed prominence in the NT, it was similarly used in the Old Testament to mean the Lord's congregation, the day of assembly or meeting before the Lord (Díaz-Pabón 2019). In ecclesiological terms, the word church is normally used in two dimensions. The first is 'local' [church], which is defined by its geographical setting and second, 'universal' [Church] which refers to the collection of believers in Christ Jesus and this church include both Jews and Gentiles (Díaz-Pabón 2019). In the NT, churches were therefore named by the cities or places where they were located. Simply put 'local church' refers to the congregation of believers of Christ limited to a particular geographical setting whereas the 'universal Church' means all believers (past, present and future) of Christ in the world. Christ is the builder of the Church: 'And I say also unto thee, that thou art Peter, and upon this rock I will build my church; and the gates of hell shall not prevail against it' (Matthew 16:18). Christ although is the builder of the Church, gives men the task to also join Him in building the Church.

We are told that historically, the early Christian church was without buildings. The first-century Christians suffered wanton persecutions and as a result had no option than to have fellowship in secret places, usually homes (Velarde 2009). Velarde therefore defines church as not a building, but a body of believers with a specific nature and purpose. Velarde continues to argue that worship, fellowship and ministry are all done by the people and not the buildings. Church structures, he argues, facilitate the role of the people of God and the structures do not fulfill it. The church is therefore a personalized practice and devotion of the believer toward God. Apostle Paul cautions Christians that salvation is an individual affair and as such they must work out their salvation with fear and trembling (Philippians 2:12). However, the individual cannot detach himself or herself from the group of believers.

It is important to stress that, Robert Velarde (2009) makes a distinction between the visible and the invisible church: 
When speaking of the church, theologians often use terms such as the visible and local church as opposed to the invisible and universal church. The visible and local church is, of course, the physical churches that we see around us and around the world, as well as the members of those churches. The invisible and universal church, however, refers to all believers everywhere and is one church, united in Christ, not many physical churches. Everyone in the universal church is a true believer, but such is not necessarily the case with visible and local churches. Why is it relevant to understand some basic differences between the visible and universal church? One key reason is so that we do not confuse what we sometimes see fallible churches doing with the reality of the universal church. Not only do visible and local churches often host nonbelievers, but also the believers themselves are imperfect, resulting in challenges and tensions in every visible church.

VELARDE 2OO9: para. 3

In the context of this study, by church we mean the 'local' or 'visible' (church) as opposed to the 'universal' (Church).

The church has many roles to play both physically and spiritually. In this section, we present four fundamental roles or functions of the church. We must note that every church must have a purpose and vision. The duties and roles of the church are inherent in its purpose and vision. As the assembly of Christ on earth, no true believer can say he or she is staying at home to serve God unless there is a peculiar challenge such as in times of violent conflict, pandemic and disaster where believers would not have the opportunity to meet together physically. It is therefore mandatory for everyone who believes in Christ not to forsake the regular gathering of believers: 'Not forsaking the assembling of ourselves together, as the manner of some is; but exhorting one another: and so much the more, as ye see the day approaching' (Hebrews 10:25 [KJV]). Some of the roles of the church are discussed in the subsequent sections.

\section{1}

\section{A Place of Worship and Praise}

The church is seen as an avenue for believers to come together to worship and praise God. Human beings were created primarily to praise and worship God, hence the need to worship Him. Worshipping God is the sum of all activities in the church and the duty of man to God. It encompasses every activity of the 
church and this is why it is the primary function of the church. One may argue that if church is limited to only worshipping then can the believer not worship God at home or alone? Yes! One can praise and worship God at home but according to the sound Christian church doctrine, God is much happier when believers worship Him in unity.

We are told that the early Christians worshipped God in unity and with one accord. It is important to note that worshipping God cannot be confined to a particular place. It is for this reason that Christ declares that where two or more people are gathered in His name, He is in their midst (Matthew 18:20). The church is set apart and dedicated to the worshipping of God. The church therefore is a place of divine worship. It is from this conception that we derive its origin from the Greek word, Kuriakon, meaning the "Lord's House" which personifies the idea of something sacred (Regester 2004). Even as a building, the church is set apart from any other structure. Regester notes that:

The consecrated character of the church should have distinct recognition in use and conduct. The building has been thereby 'separated from all unhallowed, worldly, and common uses.' It is wrong to use it for purposes of amusement or business. It has been given to God. It has been consecrated for religious purposes. It is sacrilege to treat it as a common thing.

Regester 2004: para. 8

Indeed the church as a place of worship is very crucial for believers as it provides the chance to feel very close to God, to meet other Christians with common religious beliefs and to express their faith on regular basis (Bitesize n.d). In the church believers can praise and worship God through music, dancing, giving, prayer, fasting and studying the Word of God among others. It is very interesting to note that all these activities can also be personalized.

\subsection{The Church as a Place of Serving God}

Apart from praise and worship, the church as a religious and sacred institution exists to serve God. It must be noted that, one distinguishing trait of the believer is that he is a servant. Thus, every Christian is a servant. Therefore, the church gives the believer that opportunity to serve God. To serve God entails a lot and according to Christians, He has given every believer a special gift so that they can all come together to serve Him very well. Some have been called to be inter alia: pastors, preachers, apostles, evangelists, drummers, singers, prophets, ushers, cleaners, healers, counselors and teachers. As Apostle Paul admonishes Christians, they are all one Body of Christ (1 Corinthians 12:12-30). Believers must therefore serve God with everything that they have. According 
to Christianity, all the special abilities that God has given each Christian must be used to serve and glorify Him.

After God created everything, He created man to be in charge of all creation. This was the beginning of the servanthood of man. The Christian cannot therefore worship God without serving Him. Again, in Christianity serving God is not limited to any particular group of persons. According to Christian doctrine, once a believer has a personal relationship with God, he must definitely serve Him in any capacity that he can. The act of serving God is an act of gratitude that believers show to God for creating them. This implies that Christians must take care of all the creations of God and the church exists to guide believers in doing all these. God has created humankind in a way that they can serve Him. Serving God practically is also working for Him. Christians hold the fundamental promise that they will be rewarded for serving God. For instance, in 1 Corinthians 15:58 they have been assured that nothing they do for God will ever be useless. It is said that working or serving God is the highest paid job. However, Christians often forget this since they do not receive any physical cash as they receive their wages and salaries in their jobs.

\subsection{The Church as a Place of Meeting both the Spiritual and Physical Needs of Believers}

The church has the function of meeting both the spiritual and physical needs of the believers. This was a distinct hallmark of the early church. We are told that they sold their belongings and properties to help one another. This they did faithfully with the love of Christ as the foundation. This is what Ananias and Sapphira failed to do (Acts 5:1-11). Meeting the needs and interests of the members of the church must therefore be a priority. In actual fact, the church is seen as a family and just as we try as much as possible to meet the needs and interests of the child, the father and the mother, the church must replicate same. This calls for the leadership of the church in general and the pastor in particular to identify the needs and interests of the members. The International Journal for Pastors notes that:

Pastoral ministry can be compared to a father and mother with several children. Each child requires undivided attention from their parents, and may practice negative attitude and exaggerated actions to call for this parental notice. What do these offspring really desire? Special attention. As in a family, the pastor needs to be aware of the needs and desires of each church group. What do they wish to accomplish in the church setting or in the community? How could they work together in the district to accomplish their goals and dreams for the advancement of the gospel?

Ministry 2009: para. 6-7 
When the church really cares about the needs of the congregation, it will grow both spiritually and physically. Inasmuch as the church is fundamentally a place of meeting the spiritual needs of believers, meeting the physical needs is equally important. In the real Christian sense, the overall spiritual expectation of believers from the church is its ability to provide the conduit for them to stay connected to Christ and establish the right relationship with Him. This could be achieved through sermons, prayers, teachings and all other relevant spiritual activities. Thus, in this way believers will be able to overcome spiritual challenges that obviously will drive them away from Christ. This is because they will be able to bear only fruits of the Holy Spirit that will lead them to eternal life and avoid bearing all forms of fruits of the flesh which will lead them to eternal condemnation. Examples of the fruits of the flesh as espoused in the Bible include: lust, unforgiveness, malice, gossip, dishonesty, fornication, adultery, hatred, selfishness, lies, immorality, drunkenness, witchcraft and so on. The needs of believers in the church could also be physical where the church does not need to pray for long hours seeking for a miracle. You cannot rule out prayers (which is the main weapon of believers) in all physical needs in the Christian sense but these are needs that are very tangible that the heathen and the unbeliever can also meet. The love of God must therefore drive the church toward this direction. Examples of the physical needs include: visiting the backsliding member, the sick, feeding the hungry, clothing the poor and helping the homeless among others. ${ }^{2}$ The needs could also be emotional such as the ability to overcome depression, anxiety, hurting, grief, loneliness, abandonment and hopelessness based on the Word of God.

Admittedly, identifying the needs of believers is not easy for every church. It is in fact a difficult task for the church today. Thus, it is not meeting the needs of the people that is difficult but identifying or knowing the problem of the people. If a member does not come out with a peculiar need, the church leaders and ordinary members might not know. The problem must first be identified before the solution. Some members are also likely to abuse the privilege they enjoy and see the church as a welfare association rather than a spiritual institution. It becomes more problematic when the congregation is a very large one with weak decentralization such as cell and family groupings where each member can easily be known by the group.

When the early church saw their numbers increasing and to ensure effective monitoring and management of the members, the seven deacons were appointed to specifically have time for the people. This was to avoid division in the church whiles the other apostles concentrated on the preaching of the gospel which was the main duty of the church (Acts 6:1-15). Nevertheless, the church must put up all the necessary measures to help in addressing the needs 
of the members. It is a fact that as a human institution as well, the church cannot satisfy all. This task involves an all-hands-on-deck approach involving the leadership of the church and the individual members. Human needs are insatiable and these include the spiritual as well as the physical. Of all the needs, the spiritual needs are the most important since they manifest in the physical and emotional needs. When Christ came to this earth, He always identified the needs of His followers and listeners and gave them the necessary attention. In fact, only God can satisfy the spiritual needs of the believer because He created man as spiritual being (Fletcher 2013). Christianity teaches that He even knows the needs of man more than man himself. The church must avail itself to be used as a vessel to meet the spiritual, physical and emotional needs of the members. When a church is able to meet the needs of its members, it moves beyond its confinement to meet the needs of the community at large. This has given rise to faith based organizations building hospitals, schools and providing other social amenities for some communities.

\subsection{Mission and Evangelism as a Function of the Church}

The last role of the church to be discussed which is very fundamental and uncompromising is mission and evangelism. These two core duties of the church are obedience to the Great Commission. They are the main tasks of the church. God expects believers to worship Him by saving others too for them to have the self-conviction of eternity. Mission and evangelism require believers to tell others about the love of God shown to humankind through Christ. It is about the redemptive message of the Cross and the saving faith in Christ (Ogunewu 2014). Any church that does not make mission and evangelism a priority is a lost church by itself and just a mere building wasting space. Mission and evangelism do not mean the same thing. They are different. Mission is larger than evangelism although both flow from one thing - the Great Commission. Mission is the activity that crosses cultural and language barriers. In other words, mission is mega-evangelism. Mission is God's commissioned call to announce the gospel whereas evangelism is the placement of the gospel wherever the people of God are authorized to take it anywhere on this earth (Adams 2010).

Mission involves the learning of new language and new culture of a particular place where there is no church in which people do evangelism of those in that particular culture (Piper 2009). Mission is therefore proclaiming the Good News to people of a different culture who do not have someone in their culture to do that, whereas evangelism is proclaiming the message to people that you are well familiarized with in terms of language and culture. Mission therefore involves the frantic effort to reach out to the lost in a different 
cultural setting. A clear example was the missionary activities in Ghana when the Europeans came to the Gold Coast to preach the Good News to the natives and converted them to Christianity. Those who involve themselves in missions are called missionaries. It requires more dedication and passion. Matt Smith helps us with the dichotomy between these two intertwined concepts. He posits that:

In order to "reach" a people group, some type of language and/or cultural barrier must be crossed. This is the definition of missions, crossing a cultural barrier to share the gospel with a people group. Once that group has been reached, then evangelism needs to be done to bring all the members of that group to the Lord - that's evangelism - when someone from their own people group shares the gospel with others in their people group.

SMITH 2016: para. 2

The renowned Evangelist, Billy Graham notes that:

Christian mission is unique in the aggressive movements of history. Christianity in its pure form has no 'axe to grind,' no system to foster, and no profit motivation. Its job is simply to 'seek and to save that which is lost'. Nothing more, nothing less.

GRAHAM 2O2O: para. 1

The origin of evangelism is rooted in three Greek words:

- euangelion - "gospel" - to describe what is said (Mark 1:14-15)

- euangelistes - "evangelist" - to describe the person who is telling the gospel (Acts 21:8; Eph. 4:11)

- euangelizo - "to proclaim the gospel" - to describe the activity of telling the gospel (Rom. 10:15) (Bouma 2018: para. 6).

On the nature of evangelism, the Lausanne Covenant (paragraph 4) notes that:

To evangelize is to spread the Good News that Jesus Christ died for our sins and was raised from the dead according to the Scriptures, and that as the reigning Lord He now offers the forgiveness of sins and the liberating gift of the Spirit to all who repent and believe. Our Christian presence in the world is indispensable to evangelization, and so is that kind of dialogue whose purpose is to listen sensitively in order to understand. But 
evangelization itself is the proclamation of the historical, biblical Christ as Savior and Lord, with a view to persuading people to come to Him personally and so be reconciled to God. In issuing the gospel invitation we have no liberty to conceal the cost of discipleship. Jesus still calls all who would follow him to deny themselves, take up their cross, and identify themselves with his new community. The results of evangelization include obedience to Christ, incorporation into his church and responsible service in the world.

STOTT 1975: 4 as cited in OGUNEWU 2014: 67-68

Although the onus of spreading the gospel lies on the individual believer, the church must provide that avenue. It must preoccupy itself with training the individual believer to imbibe the Christian ethos of saving others. Some believers feel very confident in sharing the gospel in groups. Others too can preach and share the testimony of Christ to others alone. Although some people have the gift of evangelism, they still need the church to nurture them to grow in the act.

The church as the assembly of Christ must show its love for Christ by reaching out to the lost. In the view of Ogunewu (2014: 67), evangelism is 'the major reproductive mechanism of the church'. This responsibility must not be left in the hands of the few. It is for this reason that every true church has a separate department for mission and evangelism. Thus, the church must invest both physically and spiritually in mission and evangelism. Mission and evangelism give every church its true identity and purpose.

In the twenty-first century, mission and evangelism pose a huge challenge to the church in this otherwise fast changing world. This is premised on the wrong assumption that through technology the gospel is preached to all nations, hence no need for massive mission and evangelism. The church must rather take advantage of the technologies which the early Christian missionaries did not have to promote and champion mission and evangelism. It must be noted that the goals of mission and evangelism are summed up into salvation for mankind. Salvation is the ultimate goal of every Christian, and mission and evangelism help the believer to be saved and stretches that saving hands of God to the lost. This is was Christians consider soul winning. The message and content of mission and evangelism are therefore very crucial. The message must be clear, direct, piercing, and devoid of ambiguities. The message of evangelism may differ in the form of presentation and articulation but its import is to tell the unsaved the love of God. The truly established church must therefore be evangelistically conscious and spiritually oriented. 


\section{Studies on Attitudes and Perceptions of Christians Concerning the Church}

Although considerable studies have been done on the attitudes and perceptions of Christians, it appears in the literature that most of these studies have focused on issues outside the church (Titilayo, Agunbiade and Kehinde 2009; Osafo et al 2013; Peprah et al 2018; Austin 2018). An attempt has been made by other scholars to concentrate on the opinions of Christians regarding some phenomena within the church (Wyllie 1985; Appiah 2015; Darko 2015). Thus, studies on the attitudes and perceptions of Christians toward the church as a spiritual organization are underexplored.

Titilayo, Agunbiade and Kehinde (2009) investigated the perceptions and attitudes of Christian youths toward condom use in Nigeria with the aim of examining the implications on HIV/AIDS. The study concentrated on unmarried Christians from $15^{-} 30$ years of age. The study was a survey research and the descriptive design was adopted. The findings of the study revealed that 43 percent of the respondents had sex before the age of 20 years. The study also found that religious commitment was fairly distributed among the participants. Again, their research revealed that the level of religiosity of respondents was a significant predictor on the knowledge of HIV/AIDS prevention. Thus, from these findings Christian doctrines and principles according to the Bible have significant impact on issues of sexuality and condom use since Christian youths with high levels of religiosity are more likely to abstain from sex.

Osafo et al (2013) also investigated the influence of religious factors on attitude toward suicidal behavior in Ghana. They employed the qualitative research approach in their study and in all, twenty-seven adult participants from both rural and urban settings were interviewed. Their study found that religious factors positively influenced the attitudes of people toward suicidal tendencies and that such people are committed to their religious beliefs. Their study found out that the principles of the Christian faith guide behaviors of believers away from committing suicide and compels them to help those battling with suicidal thoughts. Their study again revealed that Christians most especially cite the scriptures to clarify their opinions on suicide.

Similar to Osafo et al (2013), Austin (2018) examined religious perceptions of suicide and its outcome for suicidiology advocacy in Nigeria. He examined a number of religious attitudinal perspective on suicide including Islam and Christianity. Thus in his study the perceptions of Christians toward suicide is explored. Although Austin was not clear with the methodology of his study, he made a general observation that Christianity values life as sanctity and 
thus condemns the act of one taking his or her own life. Austin did not base his study on empirical analyses of the views of followers of a specific religion. However, he argues that although the Bible is inexplicit on suicide, Church Fathers such as St. Augustine and St. Thomas Aquinas who strongly condemned suicide based their arguments on the value attached to life. The position of the Church Fathers especially St. Aquinas led to the criminalization of suicide throughout the Middle Ages. Austin therefore calls on the church and other religious organizations to mount formidable advocacy for the reduction of suicide in Nigeria.

Appiah (2015) examined the attitudes of Christian pastors and leaders toward leadership succession, for leadership continuity in Charismatic and Pentecostal churches in Ghana with a case study in Kumasi. His study relied on the qualitative method of data collection through in-depth interviews and mono method of analyzing the data. Appiah contributes to the better understanding of character, attitude and motivation, and highlighted certain invisible traits (such as fear, self-centeredness, ego and unforgiveness) of leadership succession failures in the church as an organization.

In a study, Peprah et al (2018) sought to explore the attitude and health perceptions of faith healing users in urban Ghana. They thus examined the relationship between religion and health. Through exploratory research design which was qualitative in nature, their study found that faith healers are the first point of call for disease prevention and curing for most users. Thus, their study shows a positive relationship between attitudes of faith users and faith healing. In their research, it was indicated that majority of the users were Christians which made their study very important. Thus, majority of Christians therefore have positive attitudes and perceptions toward faith healing. They concluded in their research that users have positive attitudes and perceptions toward faith healing and stressed the importance of policy integration that blends faith healing into medical practices.

As gleaned from the literature most of the studies done on the attitudes and perceptions of Christians have largely concentrated on developments outside the church. This study although adds knowledge to the existing literature on general studies on the attitudes and perceptions of Christians toward a particular phenomenon, it directs the attention of church scholars to investigate the changing nature and developments of the church from the perspective of the church members in addition to personal observations. The study therefore contributes to the limited studies on the attitudes and perceptions of Christians on issues within the church, rather than issues which are outside the church as revealed in the literature. 


\section{$5 \quad$ Method}

The study largely relied on the quantitative research method. In terms of the research design, the study relied on case study in which some selected municipalities in the Greater Accra Region were used for the research. With regards to the sources of data, the study relied solely on primary source. The primary data were in the form of interviews through the distribution of structured questionnaires. Five hundred members of the church were targeted (of which 455 were actually interviewed). The targeted population was adult Christians from 18 years and above within five selected municipalities in the Greater Accra Region of Ghana. These municipalities were La Nkwantanang-Madina Municipality, La Dade-Kotopon Municipality, Adentan Municipality, Ayawaso West Municipality, and Ledzokuku Municipality. Due to some methodological challenges such as funding and the Covid-19 pandemic (which made data collection very difficult) the researchers decided to settle on these five municipalities to give a fair representation of Christians (church members) within the Greater Accra Region. The study employed the stratified and simple random probability sampling techniques. The stratified sampling technique was used to select the five municipalities whilst simple random sampling technique was used to select participants from each of the selected municipalities where every Christian 18 years and above had an equal chance of being selected in the research process. The data were analyzed using the Statistical Package for Social Sciences (SPSS) version 20. Data were presented in the form of tables and figures. In conducting a scientific research, there is always the need to follow the necessary ethical conditions. As a result, the consent and confidentiality of all respondents were strictly adhered to, and respected.

\section{Results and Discussion}

This section presents the results and discussion of the findings based on the objectives of the study.

\subsection{Demographic Characteristics of Respondents}

The results in table 1 show the demographic features of respondents. In terms of sex, majority of the respondents ( $5^{2}$ percent) were females whereas 48 percent were males. These results confirm the existing statistics of females being dominant over their male counterparts in terms of numerical strength and advantage. Most churches in Ghana and elsewhere are dominated by females. There is an increasing notion that for one to establish a church he or she should target women. It is believed that women are more receptive to issues of the church 
than their male counterparts hence they continue to overshadow males in the church. This has some biblical connotation. Women largely pride themselves of the significant role of women in the Bible for the New Testament Church. For instance after the resurrection of Christ, He appeared to women first.

With regards to the age distribution of respondents, majority (67 percent) were between the ages of $18-30$ years. This was followed by those between 31-40 years (21 percent). Next were those between $41^{-}-50$ years representing 9 percent. Those who were between $51^{-6}$ o years represented 2 percent of the respondents. The least were those from 61 years and above who constituted only 1 percent. In Ghana, the youth are those normally between the ages of 18-40 years and they constitute majority of the fraction of the population. In churches too, the youth make up the largest of the congregation. Majority of the respondents ( 81 percent) belonged to the youth category. It is said that any church that does not have youth does not have a future. The youth do not only constitute the reproductive age category of the nation but in the church as well. In Ghana, the youth are normally the first point of call when it comes to activities that have to do with physical strength in the church.

In terms of the level of education of respondents, a higher percentage of respondents (34 percent) had education up to the Senior High School level. This was followed by 29 percent who had education up to the university level. Next were those who had education up to O/A level constituting 23 percent. Five (5) percent also had education up to Junior High School level. Following that were those who had education up to teacher training level constituting 3 percent. Those who had education up to the primary school level constituted 2 percent, and technical university (Polytechnic) level 2 percent. Only 2 percent of the respondents did not have formal education. Thus, overwhelming majority of the respondents (98 percent) had formal education in one way or the other. This is very important in the conduct of the study as respondents are able to comprehend most of the issues raised in achieving the objectives of the study.

With regards to the marital status of the respondents, an overwhelming majority (75 percent) were singles. This was followed by 20 percent who were married. Next were those who were divorced or separated constituting 3 percent. Only 1 percent of the respondents were widowed. Thus, majority of the respondents were singles and this explains the reason why prayers for marriages continue to be on the top wish list of churches and individual believers. One cannot imagine a prayer festival of a church without attention paid to marriage.

The next demographic feature of the respondents is the occupational background. Majority of the respondents (68 percent) were students. This was followed by traders constituting 12 percent, bankers (9 percent), drivers (2 percent), teachers (2 percent) and masons constituting less than 1 percent (0.2). About 3 percent of the respondents identified other occupations such as nursing, 
fashion work and accounting. However, 2 percent belonged to the unemployment category.

With regards to the Christian denominations, majority of the respondents (57 percent) belonged to the Pentecostal/Charismatic denominations. This was followed by 41 percent who belonged to the Orthodox Christian denomination and 1 percent belonging to other denominations. Only less than 1 percent (o.9) did not belong to any Christian denomination. Thus, majority of the respondents interviewed belonged to one Christian denomination or the other. This is very important for the discussions especially on the perceptions that believers have toward churches in Ghana. These results are very important to really identify what believers like and dislike about the spiritual and physical organization of their respective churches. Thus, their personal experiences with their churches and observations inform their views about some of the growing perceptions about the church.

TABLE 1 Distribution of respondents by demographic features

\begin{tabular}{lcc}
\hline Gender & Frequency & Percentage (\%) \\
\hline Male & 217 & 48 \\
Female & 238 & 52 \\
Total & 455 & 100 \\
\hline
\end{tabular}

Age

\begin{tabular}{lrr}
\hline $18-30$ & 295 & 67 \\
$31-40$ & 93 & 21 \\
$41-50$ & 41 & 9 \\
$51-60$ & 8 & 2 \\
61 and above & 4 & 1 \\
Total & 455 & 100 \\
\hline
\end{tabular}

Level of Education

$\begin{array}{lrr}\text { Primary } & 9 & 2 \\ \text { JHS } & 24 & 5 \\ \text { SHS } & 155 & 34 \\ \text { University } & 131 & 29 \\ \text { O/A level } & 102 & 23 \\ \text { Technical university } & 7 & 2 \\ \text { Teacher Training } & 13 & 3\end{array}$


TABLE 1 Distribution of respondents by demographic features (cont.)

\begin{tabular}{lcc}
\hline Gender & Frequency & Percentage (\%) \\
\hline No formal education & 11 & 2 \\
Total & $42^{\text {a }}$ & 100 \\
\hline
\end{tabular}

Marital status

\begin{tabular}{lrr} 
Single & 339 & 75 \\
Married & 91 & 20 \\
Divorced/separated & 15 & 3 \\
Widowed & 6 & 1 \\
Total & $451^{\mathrm{b}}$ & 100 \\
\hline
\end{tabular}

\section{Occupation}

\begin{tabular}{lrc}
\hline Student & 308 & 68 \\
Trader & $5^{2}$ & 12 \\
Banker & 43 & 9 \\
Driver & 11 & 2 \\
Storekeeper & 5 & 1 \\
Teacher & 7 & 2 \\
Mason & 1 & 0.2 \\
Other & 13 & 2.9 \\
Unemployed & 9 & 2 \\
Total & $449^{\mathrm{c}}$ & 100 \\
\hline
\end{tabular}

\section{Christian sect}

\begin{tabular}{lcc} 
Orthodox & 183 & 41 \\
Pentecostal/Charismatic & $25^{8}$ & 57 \\
Other & 5 & 1.1 \\
None & 4 & 0.9 \\
Total & $45^{\mathrm{d}}$ & 100 \\
\hline
\end{tabular}

\footnotetext{
a Three (3) respondents did not response to the question.

b Four (4) respondents did not respond to the question.

c Six (6) respondents did not respond to the question.

d Five (5) respondents did not respond to the question.

NB: Sample size $(n)=455$

SOURCE: FIELD WORK, 2020
} 


\subsection{Assessment of Church Services and Activities}

Respondents were asked how regularly they attended church. It was revealed that majority of the respondents ( 51 percent) indicated they go to church very often, this was followed by 36 percent who attended church often and 13 percent who did not attend church often (see figure 1). Thus, not all Christians go to church on regular basis. It is important to note that there is the need for the believer to attend church on regular basis for some important reasons for both the believer and the church as a whole. First, going to church on regular basis shows the level of one's commitment to God. Second, it makes a Christian become consistent in his or her spiritual growth. The overall importance of going to church on regular basis is that it gives the church the right direction in building the faith and belief of its members. A church with regular attendance of its followers is a growing church and increases in its spirituality.

The results in figure 2 show the extent to which believers attend evening church services. Most churches have certain days within the week for evening prayers, Bible studies and teachings. It could also be all-night services and revivals. Fifty (50) percent of the respondents indicated that they attended evening church services and another 50 percent indicated otherwise. Thus, half of the respondents did not attend evening church services. It can therefore be deduced that not all Christians attend evening church services within the Greater Accra Region and this can have a national reflection on evening church attendance in Ghana. A number of factors may account for this. Considerations such as proximity, late closure of work, fatigue and spiritual laziness are some of the key ones. The believer would therefore feel comfortable going to church

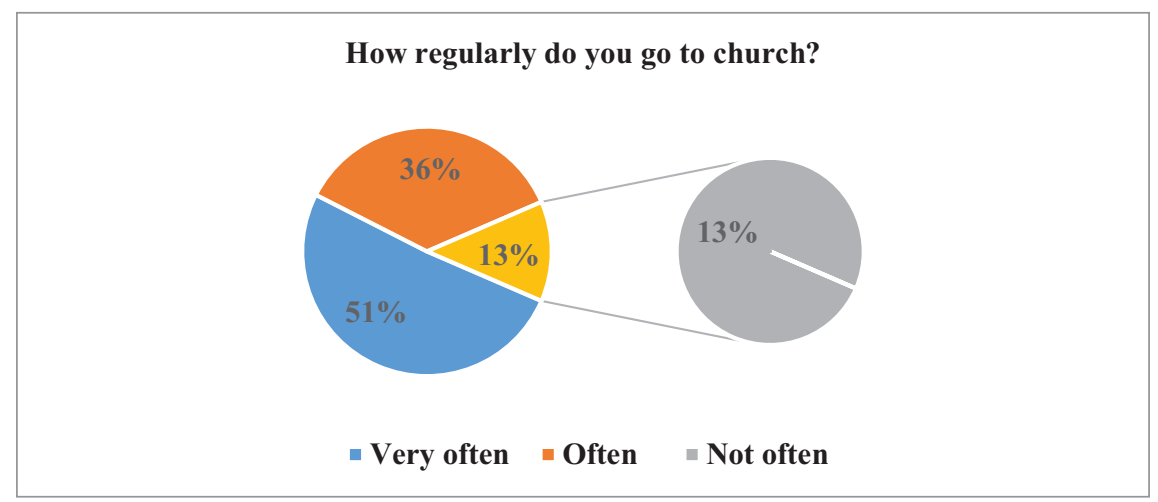

FIGURE 1 Distribution of respondents by church attendance NB: Sample size $(n)=455$ SOURCE: FIELD WORK, 2020 


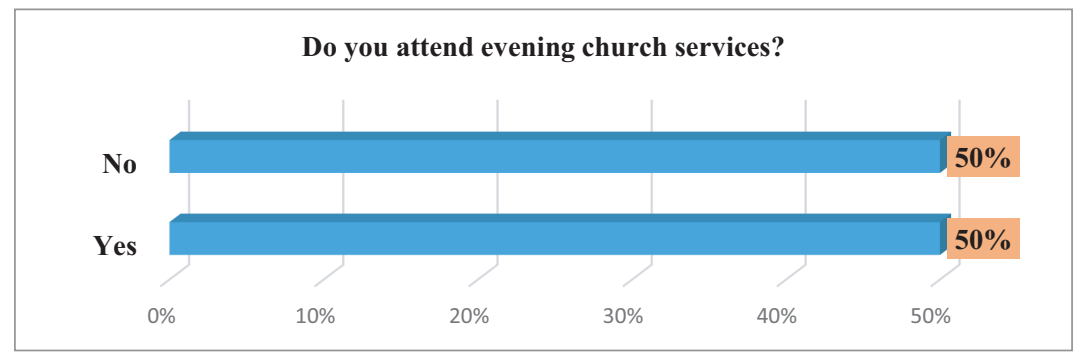

FIGURE 2 Distribution of respondents on the extent to which they attend evening church services

NB: Sample size $(n)=455$

SOURCE: FIELD WORK, 2020

only on Sundays/Saturdays which to a very large extent does not promote effective spiritual growth.

One of the chiefly reasons why Christians go to church is to listen to the message that God has for them through His messengers. One of the fundamental roles of the church is to meet both the spiritual and physical needs of the members as already noted. As to whether Sunday/Saturday sermons met the spiritual and physical needs of respondents, majority (64 percent) indicated that Sunday/Saturday sermons met both their spiritual and physical needs. This was followed by 26 percent who were uncertain about the ability of church sermons to meet both their spiritual and physical needs. Ten (10) percent affirmed otherwise that church sermons did not meet both their spiritual and physical needs. Thus, not all believers have their needs, both spiritual and physical met by the words of the preacher or pastor believed to come from God (see table 2). With the majority of the believers affirming that both their spiritual and physical needs were met by church sermons, it establishes the fact that the church which is the assembly of believers of Christ remains an important Christian and biblical institution of worship.

The results in figure 3 reveal a number of issues and developments that believers liked about their churches. A higher percentage of the respondents (33 percent) identified other things they liked about their church. These included: committed pastors, the serenity of the church, the unity and togetherness of the church, the spirituality of the church, having experienced pastors, nice looking boys and girls in the church, equity and non-discrimination, use of advanced technologies in the church, church parties and frequent evangelism of the church. Also, 17 percent identified church sermons as what they liked about the church. This was followed by 14 percent who expressed the 
TABLE 2 Distribution of respondents by whether Sunday/Saturday sermons meet both their spiritual and physical needs

\begin{tabular}{llrrr}
\hline & & Frequency & Percent & Valid percent \\
\hline \multirow{2}{*}{ Valid } & Yes & 272 & 59.8 & 63.6 \\
& No & 44 & 9.7 & 10.3 \\
& Some how & 112 & 24.6 & 26.2 \\
& Total & 428 & 94.1 & 100.0 \\
Missing & No response & 27 & 5.9 & \\
Total & & 455 & 100.0 & \\
\hline
\end{tabular}

NB: Sample size $(n)=455$

SOURCE: FIELD WORK, 2020

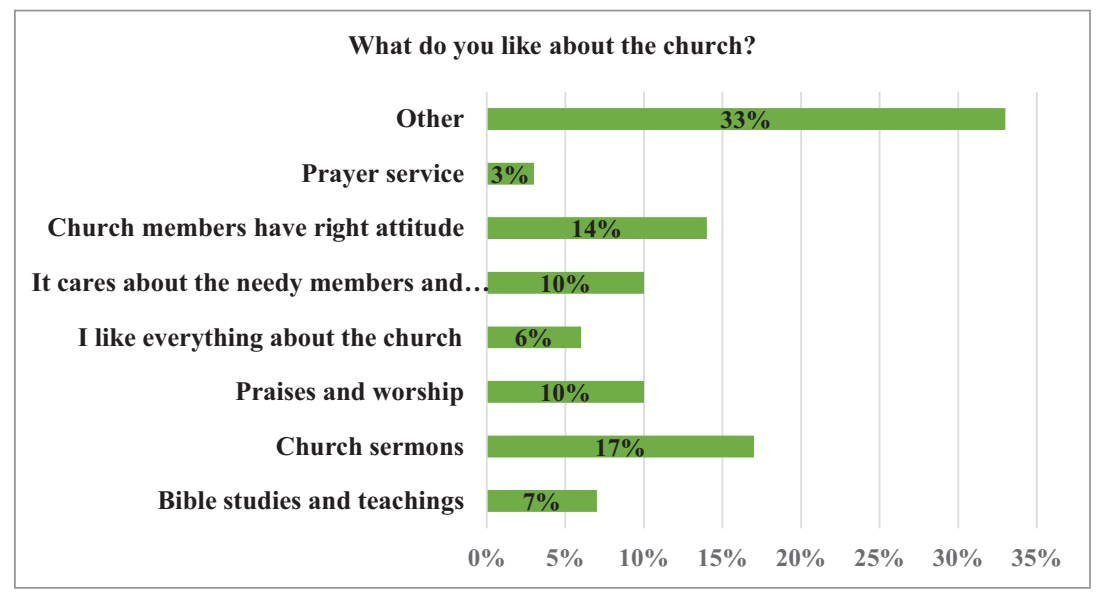

FIGURE 3 Distribution of respondents by what they like about their churches NB: Sample size $(n)=455$

SOURCE: FIELD WORK, 2020

view that they liked their churches because members have the right attitude. Examples of the right attitude stated by respondents included: punctuality, comportment during preaching, committed members, hospitality and great membership personalities. Next were 10 percent who indicated that they liked their churches because they attended to the needy members in the church and the society at large. Another 10 percent noted that they liked their church because of the praises and worship performance of the choir and praises team. Again, 7 percent indicated that they liked the church because of the Bible 
studies and teachings of the church on key Christian practices and doctrines. More so, 6 percent noted that they liked everything about their church. Only 3 percent identified prayer service as what they liked about their church. Prayer is considered as an important Christian practice and when Christ came to the earth, He taught His followers the need to be prayerful at all times. Christianity to a very large extent is a religion of warfare and the weapon of the Christian is prayer. It is therefore surprising how such an important Christian practice was considered the least important by believers.

Respondents advertently also noted some practices that they did not like about their churches. A higher percentage of the respondents (35 percent) identified other reasons that they disliked about the church. The other reasons included: inappropriate explanations of the Bible leading to poor sermons, unfaithful pastors, womanizing pastors, alcoholic pastors, long sermons, late closure of church service, lack of socialization, lack of recreational activities, boring choir, long hours of prayer, and church not caring about the welfare of members. Again 23 percent cited poor attitude of members as what they disliked about their church. The poor attitude identified by members included: hypocrisy, sexual immorality, gossip, intolerance and unwelcoming behavior of members, disobedience, problem of punctuality and laziness. Fourteen (14) percent were of the view that they disliked their churches because of the poor attitude of ushers, 11 percent identified division and discrimination within the church. There is a general concern that the church discriminates against the poor. The poor are sidelined and grossly discriminated against when it comes to important issues about the church. Also 5 percent were of the few that the church has become highly monetized and too materialistic. Some were of the view that the church takes 'too much offering'. About 1 percent also cited indecent dressing among females as what they disliked about the church which is promoting indecency and disrespect to God. The dressing of the world has gradually intruded into the church and two main general reasons have been identified for the alarming rate of indecent dressing in churches: first to get life partners and second to be noticed (Uzochukwu 2020). Whereas some churches prescribe the dressing code for their members, others have given members the liberty to dress "any how" to church. The church is an agent of change and the members of the church must live a life of example to influence the society positively. If church members have no moral training at home to dress in a decent manner, the church in the Christian context should not be a place for fashion and indecent dressing.

Further, 12 percent indicated that they disliked nothing about their churches. Thus, it can be concluded that majority of believers ( 88 percent) had issues and practices in the church that they did not like which confirm the argument 
TABLE 3 Distribution of respondents by what they dislike about the church

Frequency Percent Valid percent

\begin{tabular}{|c|c|c|c|c|}
\hline \multirow[t]{8}{*}{ Valid } & Indecent dressings & 3 & .7 & .8 \\
\hline & Poor attitude of members & 82 & 18.0 & 22.9 \\
\hline & $\begin{array}{l}\text { Division and discrimination within } \\
\text { the church }\end{array}$ & 39 & 8.6 & 10.9 \\
\hline & $\begin{array}{l}\text { Monetization and materialism of } \\
\text { the church }\end{array}$ & 16 & $3 \cdot 5$ & 4.5 \\
\hline & Nothing & 41 & 9.0 & 11.5 \\
\hline & Poor attitude of ushers & $5^{1}$ & 11.2 & 14.2 \\
\hline & Other & 126 & $27 \cdot 7$ & 35.2 \\
\hline & Total & $35^{8}$ & 78.7 & 100.0 \\
\hline Missing & No response & 97 & 21.3 & \\
\hline Total & & 455 & 100.0 & \\
\hline
\end{tabular}

NB: Sample size $(n)=455$

SOURCE: FIELD WORK, 2020

that the church will never be 100 percent purified until the return of Christ (see table 3). Most churches normally have general meetings and open forums to discuss pertinent issues for the growth of the church. These platforms help the bold members to openly voice out their grievances about the wrong direction of the growth of the church. Some churches also have suggestion boxes where members are encouraged to write down suggestions for improving the growth of the church and drop them in those boxes anytime. Some members therefore take advantage of this medium and anonymously drop their displeasures about the negative developments in the church in order not to be victimized by the church leadership and some individual members.

\subsection{Perceptions about the Ghanaian Church}

The last objective that the study sought to achieve was to examine the views of believers on some of the growing perceptions about Ghanaian churches. There is a growing perception that churches in Ghana have diluted the message of the Cross by concentrating on the message of prosperity more than repentance which leads to salvation. On this note, 43 percent and 37 percent agreed and strongly agreed respectively with this position. However, 13 percent and 7 percent disagreed and strongly disagreed respectively with this position (see figure 4). It is not a sin for the church to preach about material prosperity. 


\section{Churches in Ghana today concentrate more on the message of prosperity than repentance}

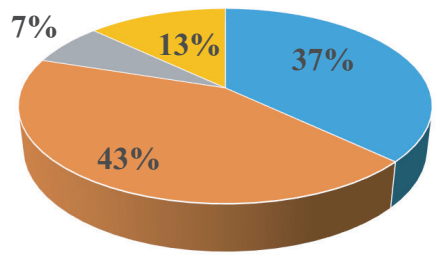

- Strongly agree " Agree " Strongly disagree " Disagree

FIGURE 4 Distribution of respondents by level of agreement on the assertion that Churches in Ghana today concentrate more on the message of material prosperity rather than repentance

NB: Sample size $(\mathrm{n})=455$

SOURCE: FIELD WORK, 2020

However, God is much interested in sinners turning away from their sins to come to Him rather than being preoccupied with material prosperities. It is for this reason that Christ admonishes His followers to seek first the kingdom of God and its righteousness and all others (including riches) shall be added unto them (Matthew 6:33). John the Baptist preached about repentance to prepare the way for Christ and when Christ began His ministry, He also preached about repentance. Again, after the Day of Pentecost, Peter in his public sermon made repentance a central focus of his message.

Respondents were also asked to show their level of agreement with the monetization and materialism of the church in Ghana. It must be noted that on what respondents disliked about the church, about 5 percent identified the monetization and materialism of the church. On this growing perception, a higher percentage of respondents (41 percent) strongly agreed with the assertion that the churches are becoming monetized and materialistic. Again about 37 percent agreed with the fact that churches are becoming monetized and materialistic. However, 14 percent disagreed with this perception and 8 percent strongly disagreed. Thus, majority of Christians interviewed (78 percent) believed that churches are becoming monetized and highly materialistic as against 22 percent who disagreed (see table 4). This act of some of the churches in Ghana (by far the majority), has been condemned by the Christian fraternity. Quansah (2019) makes the following revelation about the drifting of Ghanaian churches from the message of repentance to material prosperity: 
TABLE 4 Distribution of respondents by level of agreement on churches becoming monetized and materialistic

\begin{tabular}{llrrr}
\hline & & Frequency & Percent & Valid percent \\
\hline \multirow{2}{*}{ Valid } & Strongly agree & 178 & 39.1 & 40.7 \\
& Agree & 161 & 35.4 & 36.8 \\
& Strongly disagree & 38 & 8.4 & 8.7 \\
& Disagree & 60 & 13.2 & 13.7 \\
& Total & 437 & 96.0 & 100.0 \\
Missing & No response & 18 & 4.0 & \\
\hline
\end{tabular}

NB: Sample size $(n)=455$

SOURCE: FIELD WORK, 2020

It is very sad how, today, many pastors have abandoned the preaching of the gospel of Christ to the preaching of pop psychology and material prosperity. Acquisition of wealth and riches has become the sole motivation for many pastors in our generation. As a result, in many churches today, a good pastor is described as the one who pulls crowds and raises hundreds of Cedis during revivals and other special programs. If a pastor pulls crowds to programs, preaches to make people happy and is able to trick them through false prophetic directions to give all the money they have, such a pastor is considered to be highly anointed - 'a great man of God'. Surprisingly, the unsoundness of the message he preaches, his inaccurate and false prophetic utterances, his unbridled desire to pray for people for money against the teaching of Christ Jesus (Matt.1o:8) are swept under the carpet.

QUANSAH 2O19: para. 7-8

A further analysis with regards to the monetization and materialism of Ghanaian churches was made according to denominations (figure 5). The results show that among Orthodox Christians majority (78 percent) agreed that churches are becoming monetized and materialistic whereas 22 percent disagreed. This is not different among Pentecostal/Charismatic believers. Majority (77 percent) agreed that churches are becoming monetized and materialistic whereas 23 percent disagreed. Thus, it can be concluded that there is the growth of monetization and materialism in all Christian denominations in the Greater Accra Region and Ghana at large. It will therefore be difficult for 


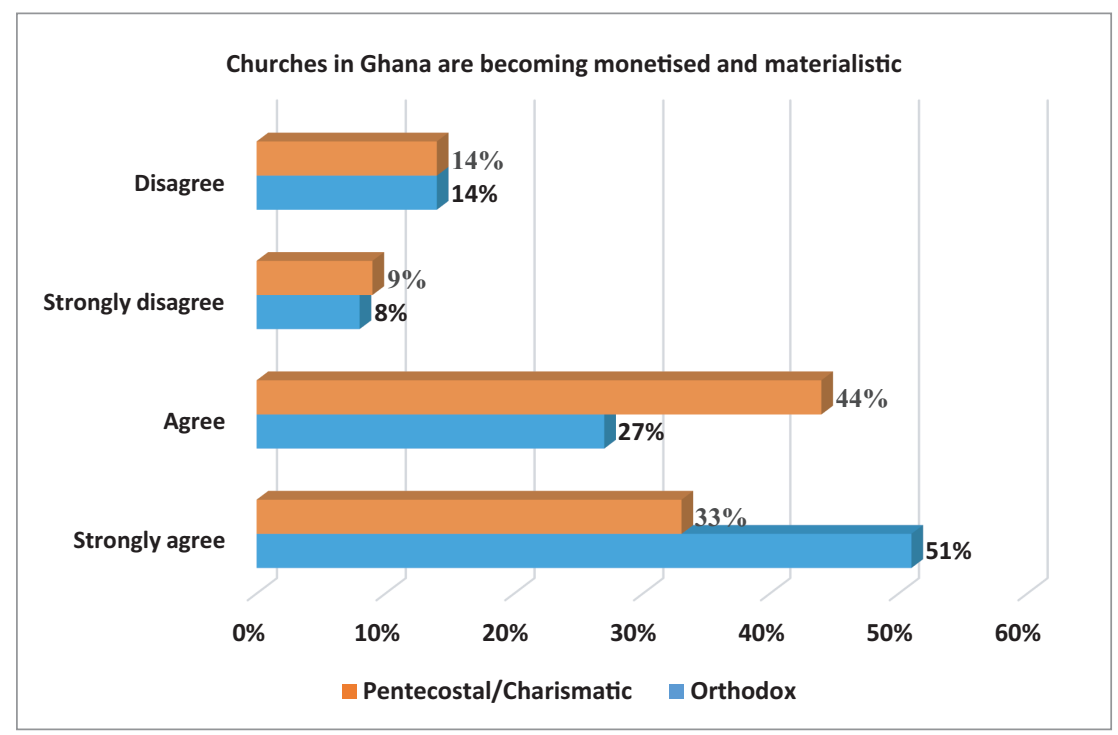

FIGURE 5 Distribution of respondents by denomination and the monetization and materialism of the church NB: Sample size $(n)=455$ SOURCE: FIELD WORK, 2020

any of these Christian denominations in Ghana to run away from this perception which had an overwhelming affirmation among believers.

It has largely been observed that majority of churches today are increasingly becoming monetized and gradually becoming economic hubs instead of spiritual enrichment centers. Globally, there is the penetration of money into the church and the worth of a church is now measured in terms of money, and this angers God (Christian Truth Centre 2020). This has eventually contributed to evil acts crippling into the church. Apostle Charles Osei Soadwa, the Head Pastor of Pentecostal Live Church, Kumasi noted that the practice of pastors milking the members of their churches for profit is highly unacceptable and is an act of indiscipline before God (Owusu-Akyaw 2017).

Of course the church in this present age cannot be ran without money. The Bible supports this assertion in the book of Ecclesiastes 10:19 (KJV): '... But money answereth all things'. God values the tithes and offerings of Christians to promote His earthly and heavenly kingdom. Christians must therefore learn to give to God. Mary Fairchild outlines the following benefits for giving to God:

- Giving shows God is Lord over the lives of believers

- Believers ought to give according to their income

- Believers are blessed when they give 
- When believers give freely to God, they receive freely from God (Fairchild 2019).

Some so called men of God in Ghana go overboard by charging people for consulting them on their spiritual needs. For instance, a popular pastor in Ghana publicly stated that he does not joke with his consultation fees (Ayamga 2020). Money is regarded as a powerful symbol of wealth and its search, a necessary phenomenon in the church (Lauterbach 2017). The message of salvation goes with evangelism but most churches have relegated this important message of Christianity and hooked unto the message of prosperity and materialism. This lacuna was also identified by the Chairman of the Christ Apostolic Church International (CACI), Apostle Dr. Stephen Kwame Amoani when he reminded Ghanaian pastors that 'the Message of the Cross' is salvation for people to live godly and responsible lives; but not the accumulation of earthly wealth" (Ghanaweb 2017). Apostle Paul in his first letter to Timothy, pre-empted him (Timothy) about the evils of money: "For the love of money is the root of all evil: which while some coveted after, they have erred from the faith, and pierced themselves through with many sorrow" (1 Timothy 6:10 [KJV]).

As noted earlier on, evangelism is a core mandate of the church and the believer. It is a command from Christ to His followers. It is therefore compulsory for the believer and the church to pursue outreach activities to reach lost souls. Also as noted in church history, it took the frantic and selfless efforts of the European missionaries to bring Christianity to the doorstep of the Ghanaian. Any church that is not evangelistically oriented has no purpose. On this not, it is encouraging to note that a higher percentage of respondents (46 percent) agreed with the perception that churches take evangelism very serious. Another 23 percent strongly agreed with this assertion. However, about 17 percent and 14 percent strongly disagreed and disagreed respectively. Thus, majority of respondents (69 percent) agreed that churches take evangelism very serious whereas 31 percent thought otherwise (see table 5 ). It is not surprising that churches keep investing in mission and evangelism activities and churches in Ghana are not in exception. It is also not surprising that some churches have instituted certain month(s) within the year for such a crusade and evangelism. Truly speaking this is not enough; this evangelism or the Great Commission work should be a daily activity. Majority of respondents largely agreed that churches take evangelism very serious. Nonetheless, the Ghanaian clergy see it otherwise. In general the individual Christian is becoming apathetic in extending saved hands to the lost. Also, majority of believers have misconstrued the basics of evangelism by thinking that it is solely the responsibility of the pastor and the leadership of the church. In 2010, the Right Reverend Dr. Yaw Frimpong-Manso, then outgoing Chairman of the Ghana 
TABLE 5 Distribution of respondents by whether churches in Ghana take evangelism very serious

\begin{tabular}{llrrr}
\hline & & Frequency & Percent & Valid percent \\
\hline \multirow{2}{*}{ Valid } & Strongly agree & 100 & 22.0 & 22.8 \\
& Agree & 204 & 44.8 & 46.5 \\
& Strongly disagree & 74 & 16.3 & 16.9 \\
& Disagree & 61 & 13.4 & 13.9 \\
& Total & 439 & 96.5 & 100.0 \\
Missing & No response & 16 & 3.5 & \\
Total & & 455 & 100.0 & \\
\hline
\end{tabular}

NB: Sample size $(n)=455$

SOURCE: FIELD WORK, 2020

Evangelism Committee (GEC), appealed to Christians in Ghana to support evangelism. He noted that:

Churches spend a lot of time, energy and money on building infrastructure and providing social services but little time, money and energy is vested in evangelism, discipleship and church growth ... Evangelism should, therefore, be the heartbeat of every living church toward the fulfilment of the divine mandate as expressed in the Great Commission of Jesus to His church.

BusinessGhana 2010: para. 3-4

Respondents were asked to show their level of agreement with the assertion that churches care much about the poor. A higher percentage of the respondents (44 percent) agreed that churches in the Greater Accra Region in particular and Ghana in general care much about the poor in the church. This was followed by 21 percent who strongly disagreed that churches in Ghana care much about the poor in the church. Also, nineteen (19) percent disagreed. The least was 16 percent who strongly agreed that churches in Ghana care much about the poor. Thus, majority of the respondents (6o percent) agreed that churches in Ghana care much about the poor in the church. However a considerable number representing 40 percent disagreed (see figure 6). The poor has always been part of the church and as a result, the church must come out with programs and activities to support the poor. This is being done by some churches in Ghana through effective general welfare policies. As already noted, 


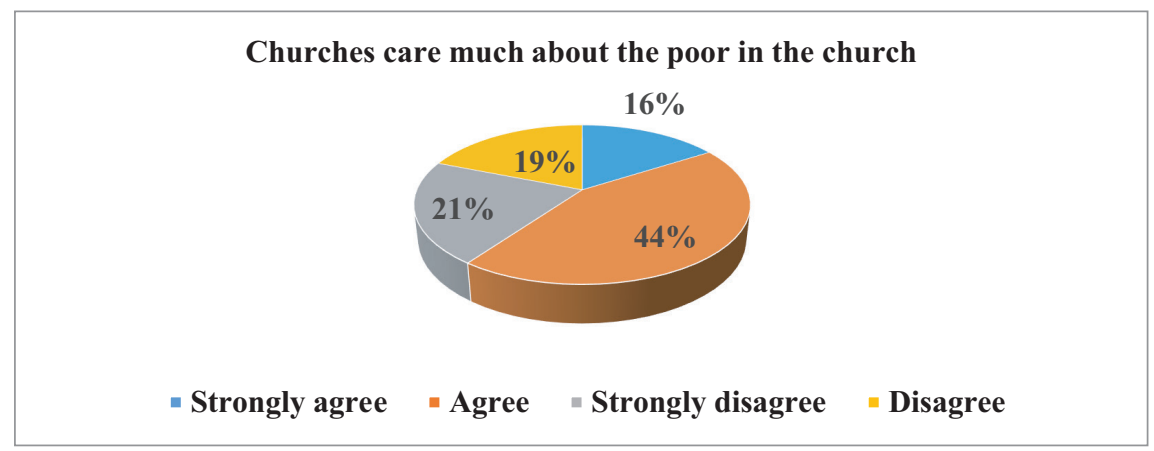

FIGURE 6 Distribution of respondents by the assertion that churches care much about the poor in the church

NB: Sample size $(n)=455$

SOURCE: FIELD WORK, 2020

it is the duty of the church to help address the physical needs of its members especially the poor.

The results in table 6 show the levels of agreement by respondents with the assertion that there is currently much division and disunity in the church than before. The results reveal that a higher percentage of respondents (43 percent) agreed that there is division and disunity in the church. This was followed by 26 percent who strongly agreed. However, 18 percent strongly disagreed and 13 percent disagreed that there is much division and disunity in the church than before. Thus, majority of believers representing 69 percent confirmed that there is polarization in the church. Although there are countless lessons for present churches to follow from the early church, issues of divisions and bitterness are permeating all facets of majority of churches. It is common to see even leaders who are supposed to set good examples for their members to follow engaging in war of words in public. Some of the most popular feuds among some Ghanaian men of God include Bishop Isaac Owusu Bempah (Founder and Leader of Glorious Word Power Ministries International) vs. Prophet Emmanuel Badu Kobi (Founder and General overseer of Glorious Wave Church International) and Rev. Ebenezer Adarkwa-Yiadom (Founder and Leader of the Ebenezer Miracle Worship Centre) vs. Bishop Daniel Obinim (Founder and Leader of International God's Way Church). Such attitudes and conducts of those who literally must know better makes Christianity unattractive to the unbeliever and this makes one wonder if the feuding parties confess and profess the same God. It has also become a common lifestyle for members of the same congregation to be at loggerheads with each other. There are also unwanted and unwarranted competitions among church departments 
TABLE 6 Distribution of respondents by division and disunity in the church in current times than before

\begin{tabular}{|c|c|c|c|c|}
\hline & & Frequency & Percent & Valid percent \\
\hline \multirow[t]{5}{*}{ Valid } & Strongly agree & 114 & 25.1 & 26.0 \\
\hline & Agree & 189 & 41.5 & 43.1 \\
\hline & Strongly disagree & 79 & 17.4 & 18.0 \\
\hline & Disagree & 57 & 12.5 & 13.0 \\
\hline & Total & 439 & 96.5 & 100.0 \\
\hline Missing & No response & 16 & $3 \cdot 5$ & \\
\hline Total & & 455 & 100.0 & \\
\hline
\end{tabular}

NB: Sample size $(n)=455$

SOURCE: FIELD WORK, 2020

and generational groups in the modern Ghanaian church. The lack of effective conflict resolutions in the church has led to some 'breakaways' or separations with the culminating effect on weak church capacity and leadership. Some Christians have also backslidden because of grudges with church leadership and members from the same church. Although this may partly depend on the spiritual maturity of the victims, it still boils down to weak conflict resolution strategies and effective communication in the church.

When Christ was praying for His disciples one thing that He placed premium on was unity. He prayed to His Father in Heaven to help His disciples live in unity, that they all may be one (John 17:21). It was through the power of love and unity that the early Christians prayed for the Angels of God to release Peter from prison (Acts 12:5-17). This is not to say that the early Christians did not have problems but they had effective conflict resolution mechanisms to deal with the dangers of divisiveness. A church that is anchored on Christ must have that divine power to resolve conflict. This is well reflected in the story of the seven deacons in Acts 6:1-15. Apostle Paul also rebuked the Church of Corinth when he suspected division within them:

And I, brethren, could not speak unto you as unto spiritual, but as unto carnal, even as unto babes in Christ. I have fed you with milk, and not with meat: for hitherto ye were not able to bear it, neither yet now are ye able. For ye are yet carnal: for whereas there is among you envying, and strife, and divisions, are ye not carnal, and walk as men? For while one 
saith, I am of Paul; and another, I am of Apollos; are ye not carnal? Who then is Paul, and who is Apollos, but ministers by whom ye believed, even as the Lord gave to every man? I have planted, Apollos watered; but God gave the increase

1 Corinthians 3:1-6 [KJv]

It is very crucial for churches in Ghana to realize the need to leverage on the importance of research to church development. A survey study that directly measures the opinions of members of the church would especially be of utility in this regard. This is a significant point to note from the findings of the study. It is therefore imperative for churches in Ghana today to constantly explore, through scientific and studious research to unearth the opinions of Christians about the church. Generally, Christians living in the Greater Accra Region attend church regularly. It can therefore be concluded that majority of Christians in Ghana have the right attitude toward church attendance. However, not all Christians have their spiritual and physical needs met by church sermons. Also worthy of note from the findings of the study is the fact that a considerable majority of Christians do not have time to attend evening church services. The study further validates the assertions that majority of churches are concentrating more on the message of material prosperity rather than repentance, beside the fact that churches today are increasingly becoming highly monetized and materialistic. It is also important to note that Ghanaian churches within the Greater Accra Region care much about the poor and also take their mission and evangelism works serious.

The study recommends that churches must on regular basis assess and document the opinions of members on the development of the church from the perspective of the members since they are the ultimate stakeholders. This will help the church to know the direction of its growth, both physically and spiritually. It is also recommended that churches in Ghana in general must come out with programs which can attract majority of Christians to attend evening church services. This will reduce the rate of apathy toward evening church attendance by Christians. It is further recommended that churches within the Greater Accra Region and Ghana in general must, as a matter of urgency stick to the apostolic foundation of Christianity which is anchored on repentance and not material prosperity. This is very imperative to prepare both believers and unbelievers about the Second Coming of Christ which is the ultimate expectation of Christians on earth. In this regard, churches must 
continue to intensify mission and evangelism activities and invest in them rather than buildings. Also, although in Christianity Jesus Christ is the perfect standard of emulation, Ghanaian pastors and pastors in general must live with the right Christian principles which is based on the Word of God in order not to be enemies of the Cross as Apostle Paul warns in Philippians 3:18. It is again recommended that churches within the Greater Accra Region and in Ghana in general that are using secular and unbiblical means to get members to give to God must desist from such ungodly conducts. This will significantly reduce the high rate of materialism and monetization of the church.

\section{Acknowledgement}

We the authors of this paper are grateful to the Almighty God for guiding our thoughts in the pursuit of this study. We are also grateful to our reviewers whose critical suggestions and recommendations improved the quality of the work tremendously. We also wish to thank Rev. Norbert Ayaamo (former Catechist of Divine Congregation [Madina NOP], Presbyterian Church of Ghana) for his perceptive review of the questionnaire for the study. We are also grateful to Dr. Solomon Kofi Amoah (Department of Sociology, University of Ghana), for the insight he provided toward this study. We also thank our Research Assistants: Harry Akyene Mokwah, Sarah Sarfo and Eunice Akawari for their roles in making this study successful. Finally we wish to thank all our respondents for consenting to take part in the study in this challenging period of the COVID-19 pandemic.

\section{Declaration of Interest Statement}

We the authors of this paper declare that there is no conflict of interest regarding the execution of this study. It was purely for academic purposes and nothing dubious.

\section{References}

Acquah, Maxwell Kobina. 2012. The Church:Is not What you Think. Cape Coast: Yefulkay Consultancy and Business Services.

Adams, Paul. 2010. The Difference between Evangelism and Mission. https://www.oscar.org .uk/blog/the-difference-between-evangelism-and-mission (Accessed: 21 June 2020). 
Appiah, David. 2015. The Attitudes of Christian Church Pastors and Leaders toward Leadership Succession, For Leadership Continuity, in Charismatic and Pentecostal Church Organizations in Kumasi, Ghana. Master Thesis, Blekinge Institute of Technology.

Austin, Omomia O. 2017. 'Religious Perceptions of Suicide and Implication for Suicidiology Advocacy in Nigeria'. International Journal of History and Philosophical Research, 5.2, 34-56.

Ayamga, Emmanuel. 2020. I Don't Joke with Consultation Fees; I can't go Hungry when I'm Working - Osofo Kyiri Abosom. https://www.pulse.com.gh/news/local/i-dont-joke -with-consultation-fees-i-cant-go-hungry-when-im-working-osofo-kyiri/86ys516 (Accessed: 5 April 2020).

Bitesize (ввс) (n.d). Significance of a Place of Worship. https://www.bbc.co.uk/bitesize/ guides/z36xk2p/revision/1 (Accessed: 21 June 2020).

Bouma, Jeremy. 2018. What is Evangelism? https://zondervanacademic.com/blog/ evangelism/ (Accessed: 28 January 2021).

Bulgakov, Sergius. 1988. The Orthodox Church. New York: St. Vladimir's Seminary Press. BusinessGhana. 2010. Christians Should Support Evangelism- Dr Frimpong-Manso. https://www.businessghana.com/site/news/general/123531/Christians-should-support -evangelism-Dr-Frimpong-Manso (Accessed: 1 February 2021).

Christian Truth Centre. 2020. Love of Money in Churches Today. https://www.chris tiantruthcenter.com/love-of-money/ (Accessed: 22 June 2020).

Clowney, Edmund P. 1987. 'The Biblical Theology of the Church'. In Donald Arthur Carson (ed). The Church in the Bible and the World. Exeter: The Paternoster Press, $13-87$.

Darko, Nora Mintah. 2015. An Analysis of Perceptions and Attitudes towards Female Pastors in two Districts in the Presbyterian Church of Ghana. Master of Philosophy Thesis, University of Ghana.

Díaz-Pabón, Luis Ángel. 2019. What is the Church? Its Role and Purpose According to the Bible. https://www.biblestudytools.com/bible-study/topical-studies/what-is-the -church-according-to-the-bible.html (Accessed: 20 June 2020).

Fairchild, Mary. 2019. What does the Bible say about Giving? Why do we Give Tithes and Offerings in Church? https://www.learnreligions.com/what-does-the-bible-say -about-church-giving-701992 (Accessed: 22 June 2020).

Fletcher, Dale. 2013. How are you Attempting to Meet your Deepest Spiritual Needs?

Ghana Statistical Service. 2012. 2010 Population and Housing Census: Summary Report of Results. Accra: Sakoa Press Limited.

Ghanaweb. 2018. Churches must Deepen Evangelism - Most. Rev. Prof. Asante. https:// www.ghanaweb.com/GhanaHomePage/religion/Churches-must-deepen-evangelism -Most-Rev-Prof-Asante-665715 (Accessed: 28 January 2021). 
Ghanaweb. 2017. Salvation is the Message, not Materialism - Apostle Amoani tells Pastors. https://www.ghanaweb.com/GhanaHomePage/religion/Salvation-is-the-message -not-materialism-Apostle-Amoani-tells-pastors-6oo156 (Accessed: 9 September 2018).

Graham, Billy. 202O. Meeting Spiritual Needs. https://billygraham.org/devotion/meeting -spiritual-needs/ (Accessed: 21 June 2020).

Gyampo, Ransford E.V and Bossman Asare. 2015. 'The Church and Ghana's Drive toward Democratic Consolidation and Maturity'.Journal of Church and State, 59.1, 1-22.

Lauterbach, Karen. 2017. Christianity, Wealth, and Spiritual Power in Ghana. London: Palgrave Macmillan.

Ministry. 2009. Meeting the needs of your Church: The Challenge of Meeting the Needs of your Church Members. https://www.ministrymagazine.org/archive/2009/12/ meeting-the-needs-of-your-church-members (Accessed: 21 June 2020).

Ogunewu, Michael A. 2014. 'The Church and Effective Evangelization in the 21st Century: Contemporary Challenges and New Approaches'. AAMM, 9.67, 66-92.

Osafo Joseph, Knizek Birthe Loa, Akotia Charity Sylvia \& Hjelmeland Heidi. 2013. 'Influence of Religious Factors on Attitude toward Suicidal Behavior in Ghana'. J Relig Health, 52.2, 488-504.

Owusu-Akyaw, Richard. 2017. Ghana: Monetizing Word of God is an act of Indiscipline. https://allafrica.com/stories/201702140694.html (Accessed: 22 June 2020).

Peprah Prince, Gyasi Razak M, Adjei Prince Osei-Wusu, Agyemang-Duah Williams, Abalo Emmanuel Mawuli \& Kote Josephine Nii Amon. 2018. 'Religion and Health: Exploration of Attitude and Health Perceptions of Faith Healing users in Urban Ghana'. BMc Public Health, 18.1358, 1-12.

Piper, John. 2009. Why Is Differentiating between Evangelism and Missions Important? https://www.desiringgod.org/interviews/why-is-differentiating-between-evangelism -and-missions-important (Accessed: 21 June 2020).

Quansah, James. 2019. Pastors, it is time to Repent. https://www.modernghana.com/ news/9076oo/pastors-it-is-time-to-repent.html (Accessed: 28 January 2021).

Regester, Jacob A. 2004. The Church, the Place of worship. https://biblehub.com/library/ regester/the_worship_of_the_church/the_church_the_place_of.htm (Accessed: 21 June 2020).

Smith, Matt. 2016. Is there any real Difference between Evangelism and Missions? https:// freedomtolead.net/evangelism-and-mission/ (Accessed: 21 June 2020).

Stefon, Matt (ed). 2012. Christianity: History, Belief and Practice. New York: Britannica Educational Publishing.

Titilayo Ayotunde, Agunbiade, Melvin Ojo \& Kehinde Okanlawon. 20o9. 'Perception and Attitude of Christian Youths toward Condom Use (Implications for HIV/AIDs in Nigeria)'. African Research Review, 3.1, 47-6o. 
Uzochukwu, Okwuagbala Mike P. 2020. Indecent Dressing and Indecency in the Church: Reasons, Causes and Effects. https://hubpages.com/religion-philosophy/Indecent -Dressing-and-Indecency-in-the-Church-Reasons-Causes-and-Effects (Accessed: 21 June 2020).

Velarde, Robert. 2009. What is the Church? https://www.focusonthefamily.com/faith/ what-is-the-church/ (Accessed: 20 June 2020).

Wyllie, Robert W. 1985. 'Perceptions of the Spiritist Churches: A Survey of Methodists and Roman Catholics in Winneba, Ghana'.Journal of Religion in Africa, 15.2, 142-167.

\section{Notes}

1 Ecclesiology is simply the branch of Christian theology which deals with the study of the church. It studies the origin, nature and mission of the church and its relationship with Jesus Christ.

2 There are some common situations where some church members stop going to church simply because they feel the church does not visit them when they are sick and in other serious challenges. It takes those who are spiritually mature to forego such reasons as a justification for ceasing to be a member of the church. This is normally realized in small congregations where the family-like nature of the church is highly felt. 